\title{
Variation of Non-syndromic Cleft Lip/Palate in Yayasan Surabaya Cleft Lip/Palate Center Surabaya, Indonesia
}

\author{
Ari Triwardhani', Ghina W. Permatasari², Jusuf Sjamsudin ${ }^{1}$ \\ ${ }^{1}$ Department of Orthodontics, Faculty of Dental Medicine, ${ }^{2}$ Undergraduate Student, Faculty of Dental Medicine, Airlangga University, Surabaya, Indonesia
}

\section{Abstract}

Objectives: Congenital anomalies are the biggest cause of prenatal, perinatal, or infant mortality and morbidity. A total of $15 \%$ of congenital abnormalities involve the craniofacial and oral segment. Orofacial cleft (OC) is one of the most common examples of congenital abnormalities. One example of OC is cleft lip and/or palate (CL/P). The occurrence of the incident varies depending on geographical location, ethnicity, race, environmental exposure, and socioeconomic status of the patients. The aim of the study was to investigate the variation of non-syndromic CL/P (nsCL/P) in Yayasan Surabaya CLP Center, East Java, Indonesia, as well as the number of occurrences of clefts in each gender. Materials and Methods: An analytical observational study with cross-sectional and blind total sampling method was presented. Data obtained from Yayasan Surabaya CLP Center were grouped by type and classified by the LAHSHAL classification system. The numbers were calculated and then divided into occurrence per gender and per family history. A descriptive analysis was applied and then presented in table form. Results: The number of patients with cleft lip and palate (CLP), cleft lip (CL), and cleft palate (CP) were 163, 57, and 16, respectively. The more detailed type: ...SHAL, .....AL, and ..HSH.., had the highest number of cases, which were 79, 28, and 10, respectively. Conclusion: Most types of CL/P at Yayasan Surabaya CLP Center were CLP, followed by CL and finally CP. The incidence of CLP and CL was more common in men, whereas CP was more common in women.

Keywords: Cleft Lip, Cleft Lip and Palate, Cleft Palate, Orofacial Cleft, Orthodontic

\section{INTRODUCTION}

Congenital anomalies are structural abnormalities that happen because of faulty development present at birth; they are considered to be the major cause of prenatal, perinatal, and infant mortality and morbidity. ${ }^{[1]}$ Congenital anomalies, also commonly referred to as birth defects, congenital disorders, congenital malformations, or congenital abnormalities, ${ }^{[2]}$ include gross and microscopic malformations, inborn errors of metabolism, intellectual disability, and cellular and molecular abnormalities. ${ }^{[1]}$ Both genetic and environmental factors and their combination in a multifactorial contest may induce congenital defects. ${ }^{[3]}$

Congenital anomalies involving the craniofacial and oral regions occur in approximately $15 \%$ of newborns, with orofacial cleft (OC) being the most common anomaly. ${ }^{[4]}$ OC may involve the lip, the roof of the mouth (hard

\begin{tabular}{|l|l|}
\hline \multicolumn{2}{|c|}{ Access this article online } \\
\hline Quick Response Code: & Website: \\
& www.jioh.org \\
\cline { 2 - 2 } & \\
\hline
\end{tabular}

palate), or the soft tissue in the back of the mouth (soft palate). It also involves structures around the oral cavity. ${ }^{[5]}$

OC includes all variations of cleft lip and/or palate $(\mathrm{CL} / \mathrm{P}){ }^{[6]}$ The incidence varies widely depending on geographic origin, racial and ethnic group, environmental exposures, and socioeconomic status. ${ }^{[7]}$ A CL/P may impact negatively on an individual's self-esteem, social skills, and behavior, especially among girls. Generally, boys are affected more than girls with a ratio of approximately 3:2. Males are more likely than females to have a cleft lip

Address for correspondence: Dr. Ari Triwardhani, Jl.
Mayjen. Prof. Dr. Moestopo 47, Surabaya,
East Java, Indonesia. E-mail: ari-t@fkg.unair.ac.id

This is an open access journal, and articles are distributed under the terms of the Creative Commons Attribution-NonCommercial-ShareAlike 4.0 License, which allows others to remix, tweak, and build upon the work non-commercially, as long as appropriate credit is given and the new creations are licensed under the identical terms.

For reprints contact: reprints@medknow.com

How to cite this article: Triwardhani A, Permatasari GW, Sjamsudin J. Variation of non-syndromic Cleft Lip/Palate in Yayasan Surabaya cleft Lip/Palate Center Surabaya, Indonesia. J Int Oral Health 2019;11:187-90. 
(CL) or cleft lip and palate (CLP), whereas females are at a slightly greater risk for cleft palate $(\mathrm{CP}) .^{[5]}$

On the basis of the problems described, this study will focus to investigate the variation of non-syndromic CL/P (nsCL/P) in Yayasan Surabaya CLP Center, Surabaya, Indonesia.

\section{Materials and Methods}

This study was first sent to the Research Ethics Committee of Dental Medicine of Airlangga University for approval (311/HRECC.FODM/XI/2018) and was carried out in Yayasan Surabaya CLP Center.

Yayasan Surabaya CLP Center is one of the charity institutes in Surabaya, Indonesia, that provides free cleft repair and maintenance. Many of the patients with cleft treated by this foundation belonged to the East Java Region. The study was conducted from October 2018, to November 2018, by looking at the patient registration data recorded from January 1, 2017 to December 31, 2017. The registration data contain information (secondary data) on general information of patients, such as name, place where he/she is living, and gender. Besides the registration, data also contain a diagnosis of clefts as well as family history information if a similar disorder occurs in family members. The inclusion criteria of this study were patients with CL, CP, or CLP abnormalities, these patients were recorded in the registration data for Yayasan Surabaya CLP Center in 2017, and these patients only experienced nsCL/P. nsCL/P is known through registration data because if there are other abnormalities, the abnormality will be noted. To find out the existence of a family history in these patients, only information in the form of "Yes" or "No" was available. So the instruments used in this study were the researchers themselves and the secondary data.

The data obtained from Yayasan Surabaya CLP Center were then copied and grouped according to the type of the CL/P. Classification used in Yayasan Surabaya CLP Center was the LAHSHAL classification system, where the "L" stands for lip, "A" for alveolus, "H" for hard palate, and "S" for soft palate. The first letter was used to code the right side and the last letter was used to code the left side and the dot was used to code for no cleft. Data were expressed as frequency. To determine the occurrence of the classified type of CL/P relative to gender and family history, further analysis using Fisher's exact test was used. $P<0.05$ was considered to have a strong association between the variables.

\section{RESULTS}

The total patients who were operated on at Yayasan Surabaya CLP Center in 2017 were 236. Patients with CLP (69\%) were the most common CL/P type of patients found at Yayasan Surabaya CLP Center [Table 1]. Variation of
CLP [Table 2] shows that cleft on the left side (...SH.L and ...SHAL) had the most cases, that is, 80 , followed by bilateral cleft (..HSHAL, LAHSH.., LAHSH.L, and LAHSHAL), with 58 cases, and last, cleft on the right side (LA.S... and LAHS...), with 25 cases. Next, for CL, most cases happened in the left side (.......L and ......AL), with a total of 42 patients, followed with cleft on the right side (L...... and LA.....), with 12 cases, and last, bilateral cleft of CL (L.....L and LA...AL), with the least cases, that is, 3 patients [Table 3]. For CP, cleft on the hard palate (..HSH..) had more patients, with 10 cases, whereas the soft palate cleft (...S...) had 6 cases [Table 4]. Of all the patients undergoing CL/P correction surgery at Yayasan Surabaya CLP Center, male patients were higher in number, with a total of 130 cases, compared to female patients, with just 106 cases [Table 5]. In the case of CLP and CL, the frequencies of patients were higher for males although not significant, whereas for $\mathrm{CP}$, the frequency of patients was strongly associated with females $(P=0.03$; $P<0.05)$. Of all the patients undergoing $\mathrm{CL} / \mathrm{P}$ correction surgery at Yayasan Surabaya CLP Center, those who did not have a family history were higher, with 183 patients, whereas those who had a family history of CL/P were just 53 [Table 6]. In the case of CLP and CL, the frequencies of patients with no family history were significantly higher

\begin{tabular}{lc}
\hline \multicolumn{2}{l}{$\begin{array}{l}\text { Table 1: Variation and percentage of patients with cleft lip } \\
\text { and/or palate at Yayasan Surabaya CLP Center }\end{array}$} \\
\hline Variation of cleft lip and/or palate & Frequency of patient \\
\hline Cleft lip and palate & 163 \\
Cleft lip & 57 \\
Cleft palate & 16 \\
\hline \multicolumn{2}{l}{} \\
\hline Table 2: Frequency of patients in each variation of cleft lip \\
and palate \\
\hline Variation of cleft lip and palate \\
\hline ...SH.L & Frequency of patient \\
...SHAL & 1 \\
..HSHAL & 79 \\
LA.S... & 11 \\
LAHS... & 1 \\
LAHSH.. & 24 \\
LAHSH.L & 2 \\
LAHSHAL & 1 \\
\hline
\end{tabular}

\begin{tabular}{lc}
\hline Table 3: Frequency of patients in each variation of cleft lip \\
\hline Variation of cleft lip & Frequency of patient \\
\hline$\ldots \ldots . \mathrm{L}$ & 14 \\
$\ldots . . \mathrm{AL}$ & 28 \\
L..... & 1 \\
L..... & 1 \\
LA..... & 11 \\
LA...AL & 2 \\
\hline
\end{tabular}




\begin{tabular}{lc}
\hline $\begin{array}{l}\text { Table 4: Frequency of patients in each variation of cleft } \\
\text { palate }\end{array}$ \\
\hline Variation of cleft palate & $\begin{array}{c}\text { Frequency } \\
\text { of patient }\end{array}$ \\
\hline ...... & 6 \\
$. . \mathrm{HSH} .$. & 10 \\
\hline
\end{tabular}

\begin{tabular}{|c|c|c|c|}
\hline \multirow{2}{*}{$\begin{array}{l}\text { Type of cleft lip } \\
\text { and/or palate }\end{array}$} & \multicolumn{2}{|c|}{ Frequency of patient } & \multirow[t]{2}{*}{ Fisher's exact test } \\
\hline & Male & Female & \\
\hline Cleft lip and palate & 91 & 72 & 0.778 \\
\hline Cleft lip & 36 & 21 & 0.172 \\
\hline Cleft palate & 3 & 13 & $0.003^{*}$ \\
\hline Total & 130 & 106 & \\
\hline
\end{tabular}

*Significant at $P<0.05$

\begin{tabular}{|c|c|c|c|}
\hline \multirow{2}{*}{$\begin{array}{l}\text { Type of cleft lip } \\
\text { and/or palate }\end{array}$} & \multicolumn{2}{|c|}{ Frequency of patients (\%) } & \multirow{2}{*}{$\begin{array}{l}\text { Fisher's } \\
\text { exact test }\end{array}$} \\
\hline & $\begin{array}{l}\text { Family } \\
\text { history }\end{array}$ & $\begin{array}{c}\text { No family } \\
\text { history }\end{array}$ & \\
\hline Cleft lip and palate & 44 & 119 & $0.012 *$ \\
\hline Cleft lip & 7 & 50 & $0.044^{*}$ \\
\hline Cleft palate & 2 & 14 & 0.373 \\
\hline Total & 53 & 183 & \\
\hline
\end{tabular}

*Significant at $P<0.05$

than that of the patients with family history $(P=0.012$ and 0.044 , respectively; $P<0.05$ ), whereas for $\mathrm{CP}$, no strong association to family history was observed.

\section{DISCUSSION}

On the basis of Smile Train organization database, every year, as many as 8900 babies in Indonesia are born with a CL/P. More than $50 \%$ of patients do not get treatment because they do not know that the cleft can be repaired free of charge, there are even a number of underprivileged patients that only pay for their transportation fee to go to the hospital. ${ }^{[8]}$ In Indonesia, there are organizations that specifically handle CL/P surgery for free, this organization is called Smile Train. Since March 2000, Smile Train has conducted free cleft operations for more than 38,000 patients in Indonesia. ${ }^{[9]}$ Smile Train Indonesia operates through its partners of more than 66 foundations and hospitals. ${ }^{[10]}$

Observations carried out on the data from Yayasan Surabaya CLP Center provide results that cleft variation is divided into three types, namely CLP, CL, and CP, which is a type of non-syndromic cleft. This is in accordance with a study conducted by Moreira et al. ${ }^{[11]}$ in 2016, which states that basically the $\mathrm{CL} / \mathrm{P}$ is divided into CLP, CL, and CP.

It was also known that the total incidence of $\mathrm{CL} / \mathrm{P}$ in Yayasan Surabaya CLP Center, which has a scope of work in East Java province for 2017, was 236 cases. This number is not much different from the data reported by Yayasan
Senyum Bali, which is also a partner of the Smile Train organization in Bali, which has a scope of work in Bali Province and has a total of as many as 244 patients with $\mathrm{CL} / \mathrm{P}$ in 2017. ${ }^{\left[{ }^{12]}\right.}$ Unlike the number of events recorded in the 2017, CoRSU Hospital in Uganda reported 355 cases of patients with $\mathrm{CL} / \mathrm{P},{ }^{[13]}$ and 2017 The Cleft Registry and Audit Network database in the UK reported 1073 patients with $\mathrm{CL} / \mathrm{P}^{[14]}$

Similarities and differences in the incidence in each city or country can occur because data collection is not carried out on the same ethnic or racial type. The size of the facial process was related to the occurrence of $\mathrm{CL} / \mathrm{P}$ because the size of the frontonasal process was in harmony with its ability to merge with other processes near it. A smaller frontonasal process similar to the ones found in Asians, which is the combination of a smaller or a more flat face with a broader upper face, and brachycephalic head can contribute to a higher CL/P level, whereas Africans with larger nose, imply that they also have a wider frontonasal process and palate, this can contribute to a lower incidence of CL/P. ${ }^{[15]}$ The possibility of this difference occurs because the density of a country compared to other countries is different.

CLP cases were ranked first when it comes to the number of patients, namely as many as 163 cases, followed by CL with as many as 57 cases, and the last one, CP with 16 cases. This is similar to the results of a study conducted by Goto et al. ${ }^{[16]}$ in 2018 in Laos, which had the occurrence of CLP ranked first, followed by CL and finally by CP. Another research conducted by Yaqoob et al., ${ }^{[17]}$ in 2013 in Pakistan, found the incidence of CP higher than that of CLP and CL. The difference in incidence can occur because the incidence of CL/P could vary in each study, depending on inclusion criteria, case definitions, data sources, and selection bias. ${ }^{[18]}$

The variation of CL and CLP at Yayasan Surabaya CLP Center has fewer bilateral cleft cases than unilateral cleft cases, and the left-sided unilateral cleft occurs more than the right-sided ones. The incidence of laterality in Yayasan Surabaya CLP Center is supported by a study conducted by Nagase et al.,$^{[19]}$ in 2010, which also obtained results that found fewer bilateral cleft cases compared to unilateral cleft cases, and more left-sided unilateral cleft cases compared to right-sided ones. One reason for the different types of laterality in the cleft is that the development of facial arteries on the left side is slower than the right side but this has not been fully confirmed. ${ }^{[20]}$

Variations in CL/P at Yayasan Surabaya CLP Center were then divided based on gender, and the result for CLP type was 91 male patients and 72 female patients, that for CL type was 36 male patients and 21 female patients, and that for $\mathrm{CP}$ type was 13 female patients and 3 male patients. In the case of CLP and CL, the frequencies of patients were higher for males although not significant, whereas for $\mathrm{CP}$, the frequency of patients was strongly associated 
with females, this is in line with the conclusion expressed in many studies such as the ones by Martelli et al. ${ }^{[20]}$ (2012), Agbenorku ${ }^{[5]}$ (2013), and especially the one by Goto et al., ${ }^{[16]}$ in Laos, which has the same ethnicity as Indonesia, that is, Asians, stating that CLP and CL occur mostly in male. ${ }^{[19]}$ On the contrary, $\mathrm{CP}$ was more prevalent in females than that in males, this result was in accordance with the research conducted by Nagase et al. ${ }^{[19]}$ (2011) in Japan, which also had the same ethnicity as Indonesia and which was conducted on 184 patients with CL/P and showed a higher percentage of females experiencing $\mathrm{CP}$ than males. ${ }^{[20]}$ As aforementioned, each type of cleft has a number of different cases for each gender, but the exact reasons that explain this incident have not yet been found. It was stated that female sex hormones may have an association and a role in increasing the incidence of $\mathrm{CP}^{[15]}$

$\mathrm{CL} / \mathrm{P}$ variation at Yayasan Surabaya CLP Center were divided based on family history. Most of CL/P patient did not have family history suffering $\mathrm{CL} / \mathrm{P}$. In the case of CLP and CL, the frequencies of the patients with no family history were significantly higher than that of the patients with family history, whereas for $\mathrm{CP}$, no strong association to family history was observed. This is contrary to the research that has been carried out because usually this disorder is an inherited disorder. So, for the other patients in Yayasan Surabaya CLP Center who did not have a family history, it is likely that other causative factors, such as alcohol, drugs, or environmental factors, were responsible. ${ }^{[5,21]}$

There are limitations to this study. As mentioned earlier, this research was carried out at the Yayasan Surabaya CLP Center, where most of the patients with cleft came from East Java. Also, this research was only carried out on those patients with registration data recorded from January 1, 2017 to December 31, 2017. With that reason, it may limit generalizability of this study.

In conclusion, most types of $\mathrm{CL} / \mathrm{P}$ cases at Yayasan Surabaya CLP Center were CLP, followed by CL and finally CP. The incidence of CLP and CL was more common in male patients, whereas $\mathrm{CP}$ was more common in female patients.

\section{Financial support and sponsorship}

Nil.

\section{Conflicts of interest}

There are no conflicts of interest.

\section{RefEREnCes}

1. Lammens M, ten Donkelaar HJ, van Vugt JMG, Noort GV, Willemsen M, Hamel B. Causes of congenital malformations. In: ten Donkelaar HJ, Lammens M, Hori A, editors. Clinical
Neuroembryology. Chapter 3. Springer-Verlag Berlin Heidelberg, 2014. p. 105. Available from: http://eknygos.lsmuni.lt/ springer/88/97-143.pdf. [Last accessed on 2019 Dec 27]

2. DeSilva M, Munoz FM, Mcmillan M, Kawai AT, Marshall H, Macartney KK, et al.; Brighton Collaboration Congenital Anomalies Working Group. Congenital anomalies: Case definition and guidelines for data collection, analysis, and presentation of immunization safety data. Vaccine 2016;34:6015-26.

3. Corsello G, Giuffrè M. Congenital malformations. J Matern Fetal Neonatal Med 2012;25:25-9.

4. Allareddy V. Orthognathic surgeries in patients with congenital craniofacial anomalies: Profile and hospitalization outcomes. Cleft Palate Craniofac J 2015;52:698-705.

5. Agbenorku P. Orofacial clefts: A worldwide review of the problem. ISRN Plastic Surg 2013;2013:1-7.

6. Crockett DJ, Goudy SL. Cleft lip and palate. Facial Plast Surg Clin North Am 2014;22:573-86.

7. Gatti GL, Freda N, Giacomina A, Montemagni M, Sisti A. Cleft lip and palate repair. J Craniofac Surg 2017;28:1918-24.

8. Smile Train. (n.d.). Kelahiran Sumbing. Smile Train. Available from: https://www.smiletrainindonesia.org/the-problem/cleft-births.html. [Last accessed on 2018 Dec 27].

9. Smile Train. (n.d.). Sejarah Smile Train. Smile Train. Available from: https://www.smiletrainindonesia.org/about-smile-train/smile-trainstory.html. [Last accessed on 2018 Dec 27].

10. Smile Train. (n.d.). Apa yang Membuat Kami Unik? Smile Train. Available from: https://www.smiletrainindonesia.org/about-smiletrain/facts-and-figures.html. [Last accessed on 2018 Dec 27].

11. Moreira HSB, Machado RA, de Aquino SN, Rangel ALCA, Júnior HM, Coletta RD. Epidemiological features of patients with nonsyndromic cleft lip and/or palate in Western Parana. Braz J Oral Sci 2016;15:39.

12. Dewi DMS. Annual Report 2017 Yayasan Senyum Bali. Available from: http://senyumbali.org/pdf/annual-report-2017-indonesia.pdf. [Last accessed on 2018 Dec 27].

13. Kirabo R, Naggi D. Annual Report 2017 CoRSU. Available from: https://corsuhospital.org/report.pdf. [Last accessed on 2018 Dec 27]

14. The Cleft Registry and Audit Network. (n.d.). Number (\%) of children born between 2008 and 2017 with a cleft lip and/or palate in England, Wales and Northern Ireland registered on the CRANE Database, according to cleft type and year of birth. The Cleft Registry and Audit Network. Available from: https://www.cranedatabase.org.uk/?!.iD=eCq. [Last accessed on 2018 Dec 27].

15. Burg ML, Chai Y, Yao CA, Magee W $3^{\text {rd }}$, Figueiredo JC. Epidemiology, etiology, and treatment of isolated cleft palate. Front Physiol 2016;7:67.

16. Goto T, Nishihara K, Kataoka $\mathrm{K}$, Goto $\mathrm{S}$, Maruyama $\mathrm{T}$, Sunakawa H, et al. Outcomes of an International Volunteer Surgical Project for patients with cleft lip and/or cleft palate: A mission in developing Laos. Congenit Anom (Kyoto) 2018;58:112-6.

17. Yaqoob M, Mahmood F, Hanif G, Bugvi SM, Sheikh MA. Etiology and genetic factors in clefts of lip and/or palate reported at Children's Hospital, Lahore, Pakistan. Indian J Hum Genet 2013;19:136-43.

18. Ahmed MK, Bui AH, Taioli E. Epidemiology of cleft lip and palate. In: Almasri MA, editor. Designing Strategies for Cleft Lip and Palate Care. IntechOpen. Available from: https://www intechopen.com/books/designing-strategies-for-cleft-lip-andpalate-care/epidemiology-of-cleft-lip-and-palate. [Last accessed on 2019 Dec 27]

19. Nagase Y, Natsume N, Kato T, Hayakawa T. Epidemiological analysis of cleft lip and/or palate by cleft pattern. J Maxillofac Oral Surg 2011;9:392.

20. Martelli DR, Machado RA, Swerts MS, Rodrigues LA, Aquino SN, Martelli Júnior H. Non syndromic cleft lip and palate: Relationship between sex and clinical extension. Braz J Otorhinolaryngol 2012;78:116-20.

21. Worley ML, Patel KG, Kilpatrick LA. Cleft lip and palate. Clin Perinatol 2018;45:661-78. 